$$
\begin{gathered}
\text { アルコール中に抽るテトラエチルアンモニウムイオンの } \\
\text { コンフォメーション平衡に関する研究 }
\end{gathered}
$$

吉 村 幸 浩 ${ }^{*}$ 後 藤 剛 史**

重 見 眞千子** 竹 清 貴 浩**

\title{
Conformational Equilibrium of the Tetraethylammonium Ion in Alcohols
}

by

\author{
Yukihiro Yoshimura ${ }^{*}$, Takefumi Goto ${ }^{* *}$, Machiko Shigemi ${ }^{* *}$ and Takahiro TAkekIYo ${ }^{* *}$
}

Conformational equilibrium of tetraethylammonium ion $\left(\mathrm{Et}_{4} \mathrm{~N}^{+}\right)$in alcohols (methanol, ethanol, $n$-propanol) has been investigated by Raman spectroscopy as functions of concentration, pressure and temperature. The difference in

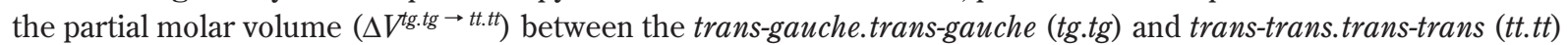
conformers of $\mathrm{Et}_{4} \mathrm{~N}^{+}$ion has been calculated from the pressure dependence of the relative Raman intensity ratio between the conformers. $\Delta V^{t g . t g} \rightarrow$ tt.tt is found to be negative throughout the studied concentration region. The value of $\Delta V^{t g . t g \rightarrow t t . t t}$ is the smallest in the methanol solution. The difference in the partial molar enthalpy $\left(\Delta H^{\text {tg.tg } \rightarrow \text { tt.tt }}\right)$ is also estimated from the temperature dependence of the relative Raman intensity. From these results, we discuss the close relationship between the conformational change and the solvation structure.

Key words : Conformation, Tetraethylammonium ion, Alcohol solutions, Raman spectroscopy

\section{1 緒言}

ハロゲン化テトラアルキルアンモニウムは，水への良 溶解性と，アルキル基の長さを容易に変えることができ る特性から, 疎水性水和を考察する上でのモデル物質と して多くの研究が行われてきた.1), 2)疎水性水和の物理的 特徵として, 溶解に伴い正の自由エネルギー $\Delta G$ 変化を 生じること, 大きな負の溶解エントロピー $\Delta S$ 変化およ び大きな正の溶解熱容量 $\Delta C_{\mathrm{p}}$ 変化を生じることが知られ ている.3), 4)この疎水性水和の起源に関する議論は現在で

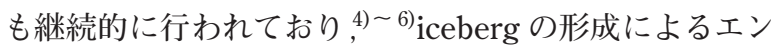
トロピー効果説 ${ }^{3)}$ や溶媒排除効果説 (cavity 理論) ${ }^{7) ~ 9) ~}$ 提案されているが, 決定的な解決に至っていないのが現 状である.

一方，テトラエチルアンモニウムイオン $\left(\mathrm{Et}_{4} \mathrm{~N}^{+}\right)$は, Fig. 1 に示すように, 溶液中で Et-N+Et を軸として, trans-trans. trans-trans (tt.tt) と trans-gauche. trans-gauche (tg.tg) と のコンフォメーション平衡が共在することが知られてい る.10), 11)我々は先の研究に打いて, テトラエチルアンモ ニウム塩水溶液中に打ける $\mathrm{Et}_{4} \mathrm{~N}^{+}$イオンのコンフォメー ション平衡が, 疎水性水和と密接な関連があることを見 出した.12)〜14)

本研究では, 疎水性水和を生じないアルコール中での $\mathrm{Et}_{4} \mathrm{~N}^{+}$イオンの tt.tt-tg.tg 平衡を, 様々な濃度, 圧力, 温 度条件下に扎いてラマン分光法により調べた。 テトラア ルキルアンモニウム塩の水溶液とアルコール溶液のラマ ンスペクトルを比較・考察することは, 疎水性水和に関 する重要な情報を提供してくれるはずである．Kannoら

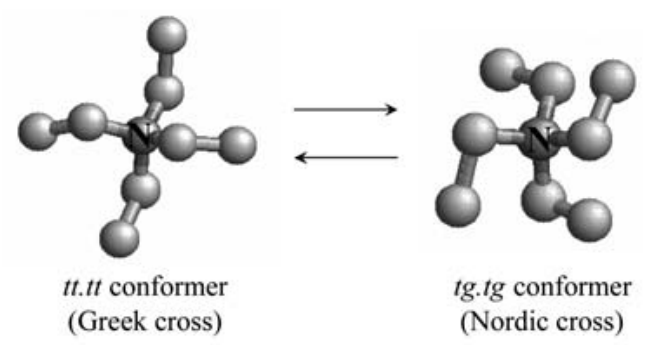

Fig. 1 Model structures of the tg.tg (Nordic cross) and tt.tt (Greek cross) conformers of $\mathrm{Et}_{4} \mathrm{~N}^{+}$ion.

は, ${ }^{15)}$ テトラアルキルアンモニウム塩のアルコール溶液

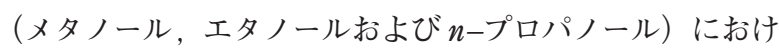
る, ラマン $\mathrm{OD}(\mathrm{OH})$ 伸縮振動に関する研究で, アルキ ル鎖の長さによるカチオンのサイズの違いは， ラマン OD 伸縮振動の波形に大きな影響を与えない, つまりラマン OD 伸縮振動に反映されるカチオンの効果は小さいと言及 している.

本研究の結果から, 水溶液中とは異なり, アルコール 溶液中においては tt.tt 体と tg.tg 体の存在比が，ほぼ均等 になることが分かった。 その他，コンフォメーション平衡 に及ぼす圧力・温度変化の測定から, コンフォメーショ ン (tg.tg-tt.tt) 間の部分モル体積差並びに部分モルエンタ ルピー差を見積り, 溶媒和構造がコンフォメーション平 衡に及ぼす影響を考察した。

\section{2 実}

験

塩化テトラエチルアンモニウム $\left(\mathrm{Et}_{4} \mathrm{NCl}\right)$ およびアルコー ル $(\mathrm{ROH} ; \mathrm{R}=\mathrm{Me}, \mathrm{Et}$ and $n$-Pr) は和光純薬製のものを使

$\dagger$ 原稿受理 平成 20 年 9 月 22 日 Received Sep. 22, 2008 @ 2009 The Society of Materials Science, Japan

* 正 会員 防衛大学校応用化学科 =239-8686 横須賀市走水, Dept. of Appl. Chem., Nat. Defense Acad., Hashirimizu, Yokosuka, 239-8686

** 防衛大学校応用化学科 T239-8686 横須賀市走水, Dept. of Appl. Chem., Nat. Defense Acad., Hashirimizu, Yokosuka, 239-8686 
用した。試料濃度は，圧力や温度を可変させた実験を行 うため，また溶液中の溶質と溶媒の存在比が容易に分か る利点があるために, $R$ (=溶媒の物質量／溶質の物質 量）で示した。ラマンスペクトル測定には，JASCO 製の NR-1800 型顕微レーザーラマン分光光度計を用いた。 レーザー光として $\mathrm{Ar}^{+}$レーザー $(514.5 \mathrm{~nm})$ を用い, 出力 は $350 \mathrm{~mW}$, 露光時間は 30 秒で行った. 得られたラマ ンスペクトルの波形解析は, 波形解析プログラム GRAMS-386 に用意されている Gaussian-Lorentzian 混合 関数を用いた．圧力発生装置として(株)協和製作所製のタ イアモンドアンビルセル（DAC：SR-DAC-KYO3-3d 型) を用い, 圧力検定はルビーチップを用いて行った. ${ }^{16), 17)}$

\section{3 結果および考察}

結果の一例として, Fig. 2 にメタノール中に打ける塩化 テトラエチルアンモニウムの $\mathrm{C}_{4} \mathrm{~N}$ 対称伸縮振動のラマンス ペクトル変化を示した。 ここで，高振動数側の $680 \mathrm{~cm}^{-1}$ 付近のピークは $t t . t t$ 体に, 低振動数側の $665 \mathrm{~cm}^{-1}$ 付近の ピークはtg.tg 体に帰属される.10)濃度が変化してもピーク 振動数の位置は，ほぼ変化がなかった。得られたスぺク トルを波形分離し, intensity fractionすなわち積分面積 強度の割合として，下記の式によりそれぞれ表した。

$$
f_{t t . t t}=\frac{I_{t t . t t}}{I_{t g . t g}+I_{t t . t t}} \quad f_{t g . t g}=\frac{I_{t g . t g}}{I_{\text {tg.tg }}+I_{t t . t t}}
$$

ここで， $f_{t t . t t}$ および $f_{t g . t g}$ は，それぞれ $t t . t t$ 体および $t g . t g$ 体の intensity fractionを， $I_{t t . t t}$ および $I_{\text {tg.tg }}$ は，それぞれ $t g . t g$ 体および $t$.tt 体のラマン散乱断面積を示す.

先の研究で, $\left.{ }^{2}\right),{ }^{13)}$ 我々は $t$.tt 体の Intensity fraction と $R$ の関係より, $t$. $t t$ 体の増加と疎水性水和との関連，すな わち $\mathrm{Et}_{4} \mathrm{~N}^{+}$イオンによる疎水性水和は tg.tg 体よりも tt.tt 体を好むことを明らかにした。一方，Fig. 3 に示すよう に，アルコール溶液の結果からは，どの溶液中に扔いて も, $f_{t t . t t}$ と $f_{t g . t g}$ の值が 0.5 付近になるということが分かっ た。つまり，疎水性水和を生じないアルコール溶液中で

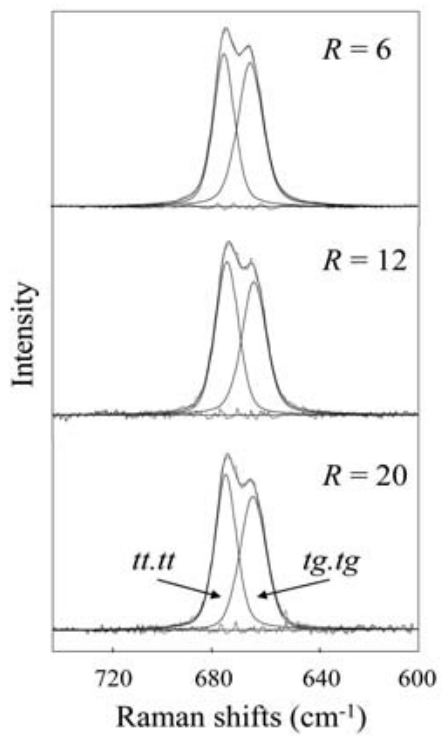

Fig. 2 Typical Raman spectra of the $\mathrm{C}_{4} \mathrm{~N}$ symmetric stretching mode of $\mathrm{Et}_{4} \mathrm{NCl}$ in methanol as a function of concentration at $0.1 \mathrm{MPa}$ and $298 \mathrm{~K}$.

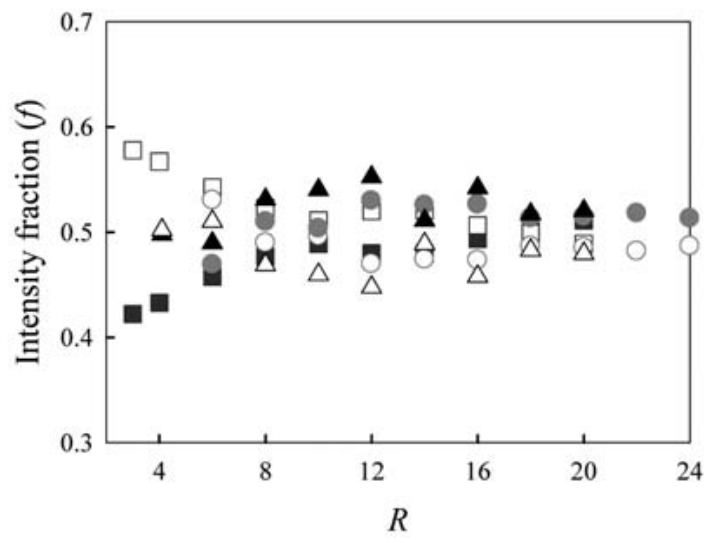

Fig. 3 Concentration dependences of the intensity fraction of the $t t . t t$ and $t g . t g$ conformers of $\mathrm{Et}_{4} \mathrm{~N}^{+}$ion in alcohol $\mathrm{Et}_{4} \mathrm{NCl}$ solutions.

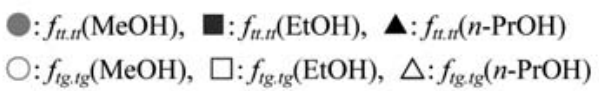

は, $f_{t t . t t}$ と $f_{t g . t g}$ の割合はほぼ $1: 1$ であり, tt.tt 体が必ず しも優勢にはならない。この傾向は, メタノール，エタ ノールおよび $n$-プロパノールで共通であり，アルコール のような疎水性水和を起こさない溶液中では, $t t . t t$ 体が 優勢でなくなると言うことができる，逆に言うと，この ことは, $\mathrm{Et}_{4} \mathrm{~N}^{+}$の疎水性水和が $t$ t.tt 体を好むことを間接 的に支持するものである.

ただし，ほとんどの溶液において，高塩濃度領域では $t t . t t$ 体の割合が若干減少（tg.tg 体の割合が若干増加）し ており，濃厚領域においては, tg.tg体の方ができやすく なることが分かった。この傾向は水溶液の場合と同様で ある。

疎水性水和作用の発現に，水の基本構造の存在の有無

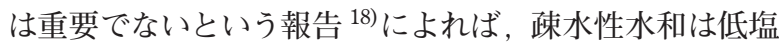
濃度領域（希薄領域）のみならず，高塩濃度領域（濃厚 領域）においても重要な役割を果たしていると言えるが, この濃厚溶液中で tg.tg 体が有利になる現象は，水溶液と アルコール溶液で共通であることから，単に濃厚溶液中 では，溶媒和するにあたり，充分な数の溶媒分子がない ため，疎水基と疎水基の重なり合い（踈水性相互作用） が起こりやすくなっていることが起因していると考えら れる。アルコール溶液中では，アルコールの疎水基と $\mathrm{Et}_{4} \mathrm{~N}^{+}$イオンの疎水基が相互作用していることも考えら れ，疎水性相互作用が生じると $\operatorname{tg} . \operatorname{tg}$ 体が増加してくるも のと思われる。すなわち, $\mathrm{Et}_{4} \mathrm{~N}^{+}$イオン周囲の環境変化 が，コンフォメーション平衡の変化として明睹に現れて いると言える。

アルコールの $\mathrm{OH}$ 伸縮振動スペクトルからも , アルコー ル溶液の構造についての重要な情報が得られると考えら れる。電解質のアルコール溶液の $\mathrm{OH}$ 伸縮振動には, 2800 〜 $3100 \mathrm{~cm}^{-1}$ に拡がる $\mathrm{CH}$ 伸縮振動スペクトルの裙 が重なるため, $\mathrm{CH}$ 伸縮振動スペクトルとの重なりがない アルコールの $\mathrm{H}$ を D で置換した重水素化アルコール (ROD) 溶液の研究がこれまでに行われている.15), 19), 20)重 水素化メタノール $(\mathrm{MeOD})$ および重水素化エタノール 
(EtOD) に，塩化テトラアルキルアンモニウム 塩化テ トラメチルアンモニウム $\left(\mathrm{Me}_{4} \mathrm{NCl}\right)$, 塩化テトラエチル アンモニウム $\left(\mathrm{Et}_{4} \mathrm{NCl}\right)$, 塩化テトラプロピルアンモニウ 厶 $\left.\left(n-\mathrm{Pr}_{4} \mathrm{NCl}\right)\right\}$ を溶解した溶液 $(R=10)$ の室温における $\mathrm{OD}$ 伸縮振動スペクトルの結果から, $\mathrm{Me}_{4} \mathrm{NCl}, \mathrm{Et}_{4} \mathrm{NCl}$, $n-\mathrm{Pr}_{4} \mathrm{NCl}$ 溶液では, 純粋な ROD よりも高振動数側に ピークが移ることが示された。このことは，塩の溶解に 伴い水素結合が弱まっていることを示している，興味深 いことは，本研究の intensity fractionの結果と同様に, 3 種類の溶液のスペクトルには，ほとんど差が見られな かったことである。さらに, MeOD 溶液と（重）水溶液 の比較 ${ }^{15)}$ からは，スペクトルの形状に大きな違いはない が, 重水溶液の方が MeOD 溶液と比較して低振動数側 にスペクトルが現れることが示された。つまり重水溶液 中では, MeOD 溶液中より強い水素結合が存在している ことになる。これは，単純な溶媒和以外の何らかの効果， すなわち水溶液中でのみ生じる疎水性水和の特徵が現れ ていると言えるのかも知れない，

テトラアルキルアンモニウム塩のアルコール溶液では, ラマン OD 伸縮振動に反映されるカチオンの効果（アル キル鎖の長さ）は小さいという報告 ${ }^{15)}$ と， $\mathrm{C}_{4} \mathrm{~N}$ 対称伸縮 振動の intensity fractionの濃度依存性に対するアルコー ルのアルキル鎖の長さによる影響が小さい事実は，少なか らず関連性があると思われ，溶媒和構造とコンフォメー ション平衡は密接な関連をもっていると言える.

Fig. 4 に $\mathrm{Et}_{4} \mathrm{NCl}$ メタノール溶液の $\mathrm{C}_{4} \mathrm{~N}$ symmetric stretching mode のラマンスペクトルの圧力依存性を示す.

結果から, 加圧に伴い $t$ t. $t$ 体の積分面積強度比は増加 し，tg.tg体のそれは減少することが分かった。この傾向 は，全測定濃度領域で同様であった．各コンフォマーの ピーク振動数は, 加圧とともに高振動数側に大きくシフ

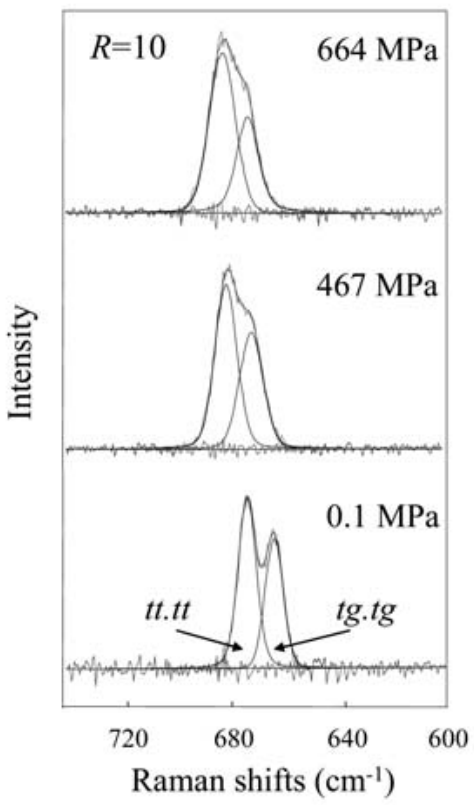

Fig. 4 Typical Raman spectra of the $\mathrm{C}_{4} \mathrm{~N}$ symmetric stretching mode of the methanol $\mathrm{Et}_{4} \mathrm{NCl}$ solution as a function of pressure at $298 \mathrm{~K}(R=10)$.
トすることが分かった，次に，各コンフォメーション間 の積分面積強度比の圧力依存性より，コンフォメーショ ン間の部分モル体積差 $\left(\Delta V^{t g . t g \rightarrow t t . t t}\right)$ を，式 $(2)$ に従い見 積った。

$$
\Delta V^{t g . t g \rightarrow t t . t t}=-8.314 T\left\{\frac{\partial \ln \left(I_{t . t t} / I_{\text {tg.tg }}\right)}{\partial p}\right\}_{T}
$$

Fig. 5 に $\Delta V^{\text {tg.tg } \rightarrow \text { tt.tt }}$ と $R$ の関係を示す. 誤差範囲は, 式 (2)による関数フィットから生じる䛊差を示している. 全測定濃度領域において， $\Delta V^{\text {tg.tg } \rightarrow \text { tt.tt }}$ の值は，基本的に負 の值をとることが分かった。つまり，コンフォメーション 変化の $t$. $t t$ 体に起因する体積は, tg.tg体のそれよりも小 さいと言える，ただし，エタノールやプロパノールのよう に，アルキル鎖が長くなると濃度変化に対する $\Delta V^{t t . t t \rightarrow t g . t g}$ の変化量は，メタノールに比べるとかなり小さくなるこ とが分かる. メタノールは $\mathrm{H}_{2} \mathrm{O}$ の中の一つの水素原子が メチル基で置き換えられた，いわば「水のアルキル置換 体」と見なすことができるが，アルキル鎖が長くなるに つれて水との類似性が失われ，むしろ炭化水素の性質に 似てくることを良く反映しているものと思われる.

次にコンフォメーション平衡に及ぼす温度効果の結果 について示す．結果の一例として, Fig. 6 にメタノール 溶液中に打ける $\mathrm{C}_{4} \mathrm{~N}$ 対称伸縮振動のラマンスペクトルの 温度依存性を示す，全ての溶液で，測定した領域におい ては温度低下に伴い $t$. $t$ t 体の積分面積強度は増加し, tg.tg 体の積分面積強度が減少することが分かった。

圧力変化の場合と同様に, 各コンフォメーション間の 積分面積強度比の温度依存性から，コンフォメーション 間の部分モルエンタルピー差は, 式 (3)に従い見積るこ とができる。

$$
\Delta H^{\text {tg.tg } \rightarrow \text { tt.tt }}=-8.314\left\{\frac{\partial \ln \left(I_{t t . t t} / I_{\text {tg.tg }}\right)}{\partial(1 / T)}\right\}_{p}
$$

すなわち，各コンフォメーション間のピーク面積強度比の 温度依存性を, van’t Hoff プロット $\left\{l n\left(I_{\text {tt.tt }} / \mathrm{I}_{\text {tg.tg }}\right)\right.$ vs. $\left.1 / T\right\}$ に して，その傾きから $\Delta H^{t g . t g \rightarrow t t . t t}$ が求められる。各溶液に

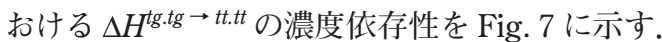

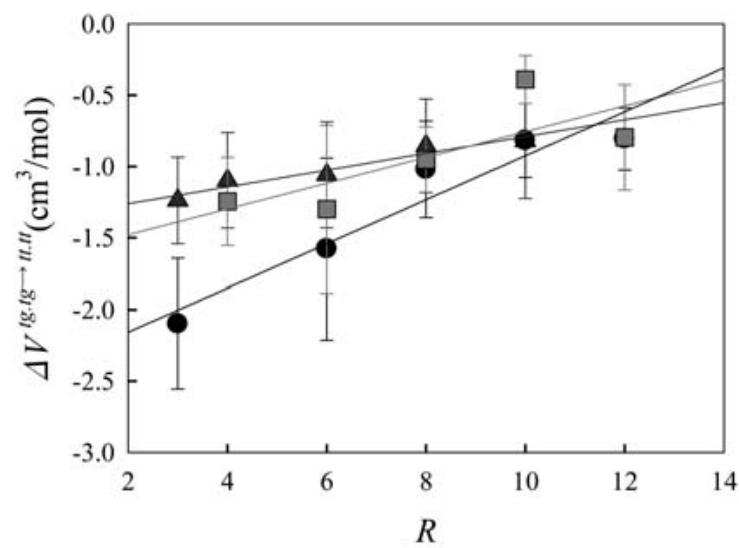

Fig. 5 Concentration dependences of the $\Delta V^{\text {tg.tg } \rightarrow \text { tt.tt }}$ of alcohol $\mathrm{Et}_{4} \mathrm{NCl}$ solutions at $298 \mathrm{~K}$.

: $\mathrm{MeOH}, \mathbf{\square}: \mathrm{EtOH}, \boldsymbol{\Delta}: n-\mathrm{PrOH}$ 


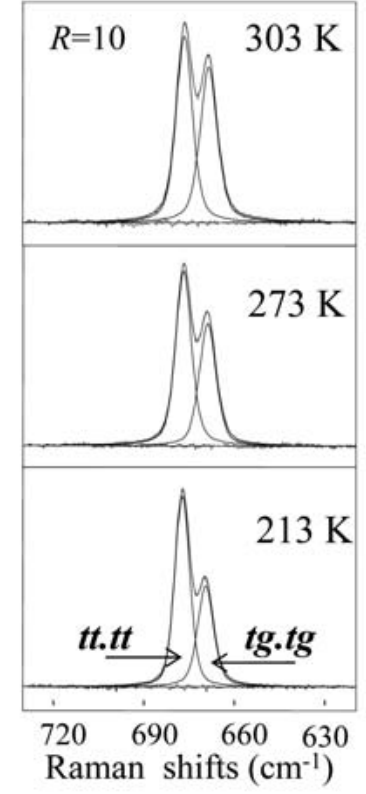

Fig. 6 Typical Raman spectra of the $\mathrm{C}_{4} \mathrm{~N}$ symmetric stretching mode of the methanol $\mathrm{Et}_{4} \mathrm{NCl}$ solution as a function of temperature at $0.1 \mathrm{MPa}(R=10)$.

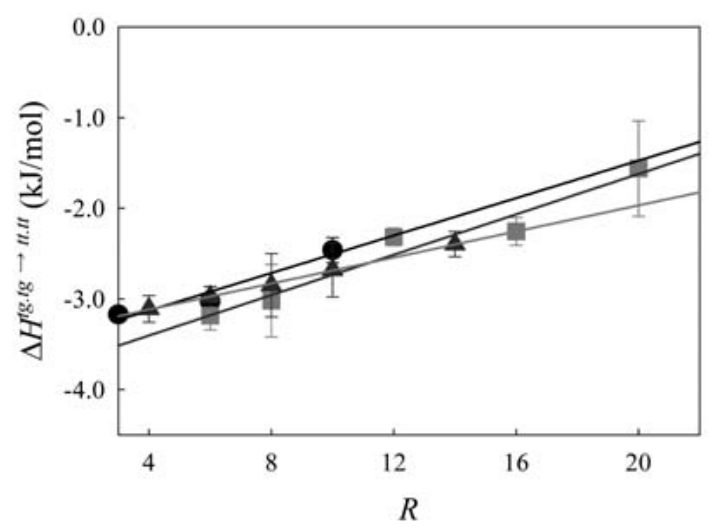

Fig. 7 Concentration dependences of the $\Delta H^{\text {tg.tg } \rightarrow \text { tt.tt }}$ of the alcohol $\mathrm{Et}_{4} \mathrm{NCl}$ solutions at $0.1 \mathrm{MPa}$.

\section{О:MeOH, $\mathbf{\square}: \mathrm{EtOH}, \boldsymbol{\Delta}: n-\mathrm{PrOH}$}

Fig. 5 と同様に誤差範囲は, van’t Hoff プロットによる 関数フィットから生じる誤差を示している. 得られた結 果から, $\Delta H^{t g . t g \rightarrow t t . t t}$ の值は測定濃度領域では全て負の值 をとることが分かった。 これは, tg.tg 体から tt.tt体へと コンフォメーション平衡が移行する方が熱的により安定 であることを示している。また，濃度が希薄になるにつ れて $\Delta H^{t g . t g \rightarrow t t . t t}$ の值が増加する, つまり tt.tt 体と tg.tg 体 のエンタルピー差が減少する傾向は, 各溶液で共通であ る。さらには, 測定範囲内では, 各アルコール間で $\Delta H^{t g . t g \rightarrow t t . t t g}$ の值の差がほとんどないことが見て取れる.

$\Delta V^{t g . t g \rightarrow t t . t t}$ と $\Delta H^{t g . t g \rightarrow t t . t t}$ の值について，水溶液の場合 に得られた結果 ${ }^{13)}$, 14) と比較すると, 両值ともアルコー 儿溶液の方が (絶対) 值が小さくなる傾向があることが 分かった. 少なくともコンフォメーション変化から見る と, 溶媒和構造の違い, すなわち疎水性水和を生じない アルコール溶液では水溶液との明確な差が結果に現れた と言える。ただし，アニオンが溶媒構造に与える影響も
少なからずあることから, 疎水性水和の解明には, さら なる系統的な研究が必要であろう。

4 結

言

本研究の成果から得られた内容は, 以下のようにまと められる.

（1）アルコールのような疎水性水和を起こさない溶液 中では, $t t . t t$ 体が優勢ではなくなることから, $\mathrm{Et}_{4} \mathrm{~N}^{+}$イオン の疎水性水和が，tt.tt 体を好むことを間接的に支持した。

(2) メタノール，エタノールおよびnープロパノール 溶液では，アルコールのアルキル鎖の長さによるサイズ の違いがコンフォメーション平衡に及ぼす影響は小さい.

（3）アルコール溶液においても, 濃厚領域で tg.tg 体 の割合が, 若干増加することが分かった。このことは, 溶媒分子が不足すると, $\operatorname{tg} . \operatorname{tg}$ 体ができやすくなることを 示している.

(4) $\Delta V^{t g . t g \rightarrow t t . t t}$ の結果から,$t t . t t$ 体周りの溶媒和の効 果による体積差は, tg.tg 体周りのそれよりも小さいこと が示された.この結果と呼応して, 部分モルエンタルピー 差 $\Delta H^{t g . t g \rightarrow t t . t t}$ の值からも, tt.tt体の方が熱的により安定 であることが分かった。

以上のような結果から，水溶液の結果と合わせて考え ると, テトラエチルアンモニウムイオンのコンフォメー ション平衡と溶某和構造には, 密接な関連があると結論 できる.

\section{参 考 文 献}

1) W-Y. Wen, "Structural aspects of aqueous tetraalkylammonium salt solutions", Journal of Solution Chemistry, Vol.2, No.2-3, pp.253-276 (1973).

2 ) S. Jain and J. C. Ahluwalia, "Differential scanning calorimetric studies on the effect of ammonium and tetraalkylammonium halides on the stability of lysozyme”, Journal of Biophysics, Vol.59, pp.171-177 (1996).

3 ) H. S. Frank and M. W. Evans, "Free volume and entropy in condensed systems III. Entropy in binary liquid mixtures ; Partial molal entropy in dilute solutions ; structure and thermodynamics in aqueous electrolytes”, Journal of Chemical Physics, Vol.13, No.11, pp.507-532 (1945).

4) F. Frank, "Water : A comprehensive treatise", Vol.2, Chap.3, (1973) Plenum Press.

5 ) K. A. Dill, "Dominant forces in protein folding", Biochemistry, Vol.29, No.31, pp.7133-7155 (1990).

6 ) L. R. Pratt and A. Pohorillc, "Hydrophobic effects and modeling of biophysical aqueous solution interfaces”, Chemical Review, Vol.102, pp.2671-2692 (2002).

7 ) R. A. Pierotti, "A scaled particle theory of aqueous and nonaqueous solutions”, Chemical Review, Vol.76, pp.717-726 (1976).

8) K. Soda, "Hydrophobic hydration of nonpolar solutes. I. Comparison of the solvation structure between water and hard-sphere solvents", Journal of Physical Society Japan, Vol.58, pp.4643-4649 (1989). 
9 ) K. Soda, "Hydrophobic hydration of nonpolar solutes. II. Analysis of the role of repulsive interactions between solute and water in determining hydration structure”, Journal of Physical Society Japan, Vol.59, pp.1093-1103 (1990).

10) C. Naudin, F. Bonhomme, J. Bruneel, D. J. Grondin, J. C. Lassegues and L. Sevant, "Rotational isomerism of the tetraethylammonium cation in solution and in the solid state", Journal of Raman Spectroscopy, Vol.31, pp.979-985 (2001).

11) V. B. Luzhkov, F. Osterberg, P. Acharya, J. Chattopadhyaya and J. Åqvist, "Computational and NMR study of quaternary ammonium ion conformations in solution”, Physical Chemistry Chemical Physics, Vol.4, pp.4640-4647 (2002).

12) T. Takekiyo and Y. Yoshimura, "Drastic change in the conformational equilibrium of tetraethylammonium bromide in the glassy aqueous solution”, Chemical Physics Letters, Vol.420, pp.8-11 (2006)

13) T. Takekiyo and Y. Yoshimura, "Raman spectroscopic study on the hydration structures of tetraalkylammonium cation in water", Journal of Physical Chemistry A, Vol.110, pp.1082910833 (2006).

14) T. Goto, T. Takekiyo and Y. Yoshimura, "Raman study on the hydration structure of Tetraethylammonium chloride in water", Journal of Physics : Conference series, Vol.121, 042005 (1-5) (2008).
15) H. Kanno and F. Hidaka, "Raman OD stretching spectral differences between aqueous and alcoholic tetraalkylammonium chloride solutions”, Chemical Physics Letters, Vol.379, pp.216-222 (2003)

16) G. J. Piermarini, S. Block, J. D. Barnett and R. A. Forman, "Calibration of the pressure dependence of the R1 ruby fluorescence line to 195 kbar", Journal of Applied Physics, Vol.46, pp.2774- 2780 (1975).

17) H. K. Mao, P. M. Bell, J. W. Shaner and D. J. Steinberg, "Specific volume measurements of $\mathrm{Cu}, \mathrm{Mo}, \mathrm{Pd}$, and $\mathrm{Ag}$ and calibration of the ruby R1 fluorescence pressure gauge from 0.06 to 1 Mbar”, Journal of Applied Physics, Vol.49, pp.3276-3283 (1978).

18) H. Kanno, Y. Yoshimura and A. Ohnishi, "Hydrophobic hydration in concentrated aqueous solution", Cryobiology and Cryotechnology, Vol.41, pp.104-106 (1995).

19) I. M. Strauss and M. C. R. Symons, "Solvation spectra. Part 54. A low temperature infrared spectroscopic study of the solvation”, Journal of Chemical Society, Faraday Transaction I, Vol.73, pp.1796-1806 (1977)

20) H. Kanno and S. Yamaguchi, "Pre-resonance Raman effect on the OD stretching Raman spectra of methanolic LiX solutions ( $\mathrm{X}=\mathrm{Cl}, \mathrm{Br}$ and I)", Journal of Raman Spectroscopy, Vol.24, pp.403-406 (1993). 